\title{
PROSPEK PRODUCT SOUVENIR KAYU KELAPA DI PINELENG MENDUKUNG INDUSTRI PARIWISATA DI SULAWESI UTARA.
}

\author{
Fonny E. H. Sangari \\ Politeknik Negeri Manado \\ Sangarifonny@gmail.com
}

\begin{abstract}
ABSTRAK
Prospek product souvenir kayu kelapa di Pineleng mendukung industri pariwisata di Sulawesi Utara. Hibah Penelitian di Politeknik Negeri Manado. Penelitian ini bertujuan (1) mengetahui prospek product souvenir kayu kelapa di Pineleng serta (2) memperoleh gambaran peranan souvenir kayu kelapa mendukung kepariwisataan di Sulawesi Utara. Penelitian ini termasuk penelitian deskriptif mengambil lokasi di Pineneleng, Art Indic Shop serta di beberapa lokasi pemasaran souvenir di Kota Manado. Data penelitian ini berwujud data kuantitatif - kualitatif tentang produksi dalam lima bulan terakhir, volume penjualan produk dalam lima tahun terkahir serta data persepsi tentang souvenir kayu kelapa dalam kontribusinya di industri pariwisata di Sulawesi Utara. Data diperoleh langsung dari lokasi objek penelitian serta tanggapan responden dalam menjawab angket yang telah disediakan peneliti. Metode pengumpulan data melalui observasi dengan melakukan pengamatan dari dekat proses pembuatan souvenir, pengambilan gambar, pencatatan data yang relevan dengan judul yang diangkat, wawancara dengan mengajukan pertanyaan kepada responden. Instrumen yang digunakan adalah interview guide, dokumentasi pengumpulan data yang relevan, baik objek penelitian maupun literatur yang mendukung penelitian. Analisis yang digunakan deskriptif kualitatif. Analisis kualitatif adalah analisis bersifat memberikan keterangan dan penjelasan objek yang diteliti. Setelah dilakukan analisis diperoleh kesimpulan bahwa; souvenir kayu kelapa memiliki prospek yang baik terlihat dari rata-rata prosentasi kenaikan lima tahun terakhir untuk produk plaket ukir $12.2 \%$, ukiran meriam $12 \%$, gayung $9.8 \%, 22,2 \%$, topeng kelapa $45 \%$ dan gantungan kunci $84.8 \%$, serta dilihat dari frekuensi tanggapan responden dari 12 responden yang tersisa karena memilih souvenir maka terbanyak coconut wood souvenir 83\% sedangkan clove souvenir $17 \%$. Ini menujukkan bahwa souvenir kayu kelapa mendukung industri pariwisata.
\end{abstract}

Kata Kunci: Product souvenir, Kayu kelapa, Industri pariwisata, Pineleng. 


\title{
THE PROSPECT OF COCONUT WOODEN SOUVENIR PRODUCT IN PINELENG TO SUPPORT TOURISM INDUSTRY IN NORTH SULAWESI
}

\begin{abstract}
This research is aimed to identify the prospect and souvenir product made of coconut wooden in Pineleng and how the souvenir product supporting tourism industry in North Sulawesi. The research is a descriptive research located in Pineleng, Art Indc Shop and several marketing places in Manado. Both quantitative and qualitative data are collected on souvenir productionin the last five months, sales volume in the last five years and the perception data on wooden souvenir and its contribution to tourism industry in North Sulawesi. Data are directly collected from the study areas, questionnaire, and field observation on the production areas for taking pictures, note taking and also interviews to several informants. Interview guide and documentation on both research objects and literature are used as instruments. Descriptive analysis is used to examine and describe the research results. This research concludes that the wooden souvenir has a good prospect representing the increase of 12,2\% for carved plaque, $12 \%$ for carving cannon, $9.8 \%$ for scoop, $45 \%$ for mask and $84 \%$ for key rings. From the rest of 12 respondents choose the souvenir from wooden coconut (83\%) and clove souvenir (17\%). This shown that wooden coconut souvenir has supported and made contribution to tourism industry within the area.
\end{abstract}

Keywords: Product souvenir, Coconut wood, Pineleng

\section{PENDAHULUAN}

Pengembangan pariwisata nasional merupakan suatu usaha yang dapat memupuk rasa cinta tanah air dan bangsa serta dapat memperkenalkan negara Indonesia di mata dunia. Keikutsertaan semua pihak dalam usaha meningkatkan pembangunan pariwisata nasional merupakan cara terbaik untuk mencapai keberhasilan dalam pengembangan pariwisata. Untuk mencapai hasil yang maksimal diperlukan usaha-usaha untuk mengembangkan dan mengelola industriindustri wisata mulai dari promosi, penyediaan fasilitas, peningkatan mutu serta pengelolaan yang berrdasarkan pada prinsip-prinsip sustainable tourism development.

Industri pariwisata Indonesia mengalami pertumbuhan yang relative cepat seperti terlihat pada peningkatan jumlah agen perjalanan (travel agent), industry penerbangan (airline) dan industry toko cenderamata (souvenir shop) yang setiap tahun bertambah. Produk pariwisata (tourism product) yang dijual oleh industriindustri ini akan memiliki nilai jual tinggi jika dikelola secara baik dan professional. Pembangunan industri pariwisata nasional dan daerah diarahkan untuk peningkatan ekonomi dan penerimaan devisa negara, memperluas lapangan 
kerja yang pada akhirnya akan meningkatkan kualitas hidup seluruh masyarakat Indonesia.

Dalam mengembangkan industri kepariwisataan suatu daerah harus memenuhi unsur-unsur penting yaitu : akomodasi, jasa boga atau restoran, transportasi atau jasa angkutan, tempat penukaran uang (Money Changer), atraksi wisata, souvenir dan biro perjalanan. Unsur ini harus dipenuhi dan dikembangkan secara berimbang agar suatu daerah dapat dikatakan berkenan dan layak menajamkan visi pengembangan pembangunan pariwisata.

Pada tahun 2009 yang lalu Sulawesi Utara umumnya dan kota Manado khususnya boleh berbangga diri dengan beberapa keberhasilan yang dianggap spektakuler untuk suatu pelaksanaan ivent konferensi yang berskala International yaitu Konfererensi negera-negara pemilik laut; WOC dan CTI Summit serta dilanjutkan lagi dengan pelaksanaan Bunaken Sail. North Sulawesi AS World Tourirsm Destination (Sulawesi utara sebagai tujuan pariwisata dunia).

Melalui program Pemerintah propinsi Sulawesi Utara dan di dukung oleh masyarakat Sulawesi Utara maka keberhasilan melaksanakan ivent tersebut telah mengembangkan industri kepariwisataan suatu daerah secara berimbang dan menajamkan visi pengembangan pembangunan pariwisata Sulawesi Utara yaitu keberhasilan menyelenggarakan kegiatan Internasional (World Ocean Confrence serta Sail Bunaken ), daya tarik pariwisata baik eco tourism ataupun non eco tourism. Keramah tamahan penduduk serta kerukunan umat beragama, peningkatan sarana akomodasi pariwisata, potensi meningkatnya investasi (dari sisi akomodasi perhotelan/restaurant), peningkatnya jalur penerbangan baik langsung maupun tidak langsung. Hal itu semua mengangkat nama Kota Manado menjadi hangat dibicarakan di mata dunia. Bahkan akan disejajarkan dengan Bali sebagai kota konferensi dan kota pariwisata dunia.

Sejalan dengan kesuksesan tersebut tentunya juga merupakan moment sangat tepat bagi pemerintah Sulawesi Utara dan kota Manado yang menajamkan visinya sebagai kota tujuan wisata dunia. Menilik tujuh unsur yang disebutkan sebagai pembentuk industri pariwisata suatu daerah maka hampir semuanya bisa dikatakan layak bagi daerah dijadikan sebagai kota tujuan wisata selain Bali, diluar faktor-faktor yang lain yang merupakan keunggulan daerah yaitu kedamaian, keamanan dan lain-lain.

Namun setelah di teliti lebih jauh ternyata ada dua unsur yang masih kurang bagi pengembangan pariwisata di Sulawesi Utara yaitu atraksi wisata serta souvenir. Bagi atraksi wisata memang tinggal di tumbuh kembangkan melalu pengembangan management yang baik karena hampir setiap daerah di propinsi Sulawesi utara memiliki atraksinya sendiri. Hanya perlu kolaborasi antar daerah.

Unsur yang lain adalah souvenir atau cendera mata ternyata untuk Sulawesi Utara masih kurang walaupun kita berbangga hati dengan beberapa tenunan kain seperti Batik Bentenan serta kerajinan lain. Ada satu komoditi andalan Sulawesi Utara yaitu Kelapa. Perkebunan Kelapa merupakan keunggulan absolut, dari rakyat Sulawesi Utara. Hampir semua bagian dari komoditi kelapa ini bisa bermanfaat bagi kebutuhan manusia.

Selain menjadi kebutuhan pokok manusia, komoditi tanaman pohon kelapa bisa dijadikan juga sebagai souvenir bagi wisatawan. Permasalahan yang ditemui 
selama ini produk kerajinan souvenir kayu kelapa di souvenir shop selama ini hampir di dominasi oleh produk-produk kerajinan dari luar daerah yang diimport; dalam arti kata belum memberikan peranan atau andil bagi industri pariwisata di Sulawesi Utara. Selain itu jika ditemukan produk asli / buatan penduduk pribumi namun belum memiliki kwalitas yang baik sesuai dengan kebutuhan, keinginan dan harapan tourist.

Manfaat yang diharapkan dalam penelitian Prospek Product Souvenir Kayu Kelapa di Pineleng Mendukung Industri Pariwisata Di Sulawesi Utara antara lain : sebagai sumber informasi dan rekomendasi bagi pengambil keputusan di daerah untuk pengembangan usaha-usaha yang sejenis yang berhubungan dengan pembangunan pariwisata, informasi bagi pengusaha kerajinan tradisional berupa industri kecil dan menengah yang di kelola oleh masyarakat untuk mampu membuat produk yang berciri khas, memperkaya khasanah ilmu pengetahuan pariwisata khususnya ekonomi berbasis periwisata di Sulawesi Utara, dimana sektor pariwisatanya sedang berkembang dan bahan acuan data penyusunan kegiatan belajar mengajar pada mahasiswa jurusan pariwisata yang akan terjun ke industri pariwisata sehingga mereka dapat melayani tamu / tourist yang berkunjung dengan service quality yang lebih baik.

Di Pineleng ada satu usaha kecil kerajinan tangan kayu kelapa yang beberapa tahun ini senantiasa memproduksi dan memasok souvenir untuk kebetuhan industri pariwisata di Sulawesi Utara. Tujuan Penelitian ini adalah untuk mengetahui prospek product souvenir kayu kelapa di Wenang Asri Pineleng dan memperoleh gambaran peranan souvenir kayu kelapa dalam mendukung pariwisata di Sulawesi Utara.

Pariwisata adalah salah satu aspek unggulan dalam upaya pengembangan ekonomi di Indonesia pada umumnya serta di beberapa tingkat propinsi dan kabupaten kota pada khususnya. Oleh sebab itu pariwisata saat ini mendapat perhatian besar baik dari pemerintah, swasta, industri pariwisata, akademisi maupun masyarakat umum lainnya. Untuk mengetahui motivasi perjalanan wisata yang dilakukan oleh para wisatawan maka sangatlah penting untuk melakukan riset atau penelitian secara berkesinambungan.

Hasil riset yang dilakukan secara langsung dengan wisatawan dapat dijadikan sebgai umpan balik guna pengembangan dan pengelolaan pariwisata yang lebih baik. Menurut Wagen (1997), II Feedback from customers is one of the most effective ways to find out how a business operation can be improved".

Berkaitan dengan hal tersebut informasi tentang tourist needs and expectation sangatlah diperlukan untuk mengetahui sekaligus mengevaluasi product quality dari pasar pariwisata Sulawesi Utara umumnya serta Manado pada khususnya. Oleh karena itu bisnis pariwisata juga tergantung pada umpan balik yang diberikan oleh wisatawan untuk secara terus menerus meningkatkan produk pelayanan

\section{Komoditi Tanaman Pohon Kelapa}

Salah satu keunggulan komparatif yang dimiliki oleh Propinsi Sulawesi Utara adalah luas areal perkebunan yang sejak zaman kolonial Belanda tanaman ini sudah di budidaya. Hal ini dikarenakan begitu banyaknya manfaat yang bisa di 
dapat dari Tanaman Pohon Kelapa. Hampir seluruh bagian dari tanaman pohon kelapa dapat diambil manfaatnya. Berikut ini beberapa komoditi tanaman kelapa:

\section{1) Batang Kelapa}

Batang kelapa banyak sekali dimanfaatkan orang sebagai bahan baku bakar, bahan meubel dan bahan tambahan pembuatan rumah. Hal ini dimungkinkan batang kelapa memiliki keunikan kayu tersendiri dan sangat kuat.

\section{2). Daun Kelapa}

Daun kelapa juga memiliki banyak manfaat terutama penduduk yang berada dikampung, mereka memanfaatkan sebagai bahan bakar dan lidi yang biasanya dijadikan bentuk anyaman dan sapu lidi. Penggunaan bahan ini pada saat kering untuk daun tetapi lidi bisa masih dalam keadaan mentah ataupun setengah kering.

\section{3). Buah Kelapa}

Buah kelapa dibutuhkan oleh manusia sebagai bahan makanan jika sudah di kelolah menjadi bahan jadi. Buah kelapa berbentuk bulat terdiri atas:

\section{Daging kelapa}

Daging dari buah kelapa berwarna putih dan banyak menjadi keunggulannya bagi kebutuhan manusia. Minyak kelapa dan nata decoco sebagai bahan buahbuahan segar. adalah bahan bakunya buah kelapa. Minyak kelapa sendiri memenuhi $10 \%$ kebutuhan minyak nabati di dunia. Secara fisik, minyak kelapa berwarna kuning kecoklatan muda. Titik bekunya pada derajat panas $18-20^{\circ} \mathrm{C}$, dan mulai mencair pada $23-26^{\circ} \mathrm{C}$.

Berat jenis 0,91-0,93, tergantung suhunya. Minyak kelapa dihasilkan lewat pengolahan langsung artinya dicukur dagingnya yang segar tapi yang sudah sedikit tua atau dijadikan syarat bahan baku kopra. Pengolahannya bisa secara tradisional dan modern juga lewat cara destilasi. Kegunaan minyak kelapa sebagai minyak goreng dan bahan baku industri lainnya. Daging dari buah kelapa dengan hasil parutan yang kering bisa juga dimanfaatkan untuk bahan-bahan kue dan itu pengolahannya memang memakai alat modern.

\section{Serat atau Sabut Kelapa (Coir Coconut Fibre)}

Serat sabut kelapa termasuk golongan serat kasar yang penting sebagai bahan perdagangan. Ada industri-industri yang menggunakan bahan baku serat ini tersebar luas di negara-negara penghasil kopra.

\section{Tempurung Kelapa (Coconut Shell Charcoal)}

Arang tempurung dihasilkan dari pembakaran tempurung buah kelapa yang sudah tua dengan cara tertentu, dimana proses pembakarannya banyak . Arang tempurung memiliki kapasitas yang tinggi dalam mengabsorbir gas dan zat-zat warna, dan dalam bentuk "actitived carbon" digunakan sebagai pengisi kedok (masker) gas beracun. Karena sifatnya sebagai bahan bakar berkalori tinggi, arang tempurung banyak digunakan oleh pandai-pandai besi, dan juga dalam proses peleburan emas dan perak. 


\section{Air Kelapa/Nira/Gula Kelapa}

Nira adalah cairan manis yang diperoleh dengan melaksanakan perlakuan khusus terhadap mayang kelapa (spatha) yang belum membuka pada umur tertentu. Adapun gula kelapa adalah bahan pemanis yang merupakan hasil olahan nira yang sejak dahulu hingga saat ini merupakan bahan perdagangan yang penting bagi rakyat pedesaan.

Bagi beberapa daerah di Indonesia yang memiliki areal perkebunan kelapa, mendapatkan manfaat dari kelapa sudah menjadi bagian dari hidup dari penduduk setempat. Bahkan di beberapa tempat telah menjadi produk kompetitif bagi daerah tersebut yang walaupan luas tanamannya tidak sebegitu luas seperti di Sulawesi Utara yang di sebut sebagai \|Coconut Landll.

Namun sampai sejauh ini pemanfaatan dari komoditi ini belumlah semaksimal yang diharapkan. Memang sudah ada beberapa produk yang dihasilkan oleh warga seperti ; rumah dari kayu kelapa, perabotan kursi lemasi, meja serta produk produk makanan yang di ambil dari buah kelapa yang telah menjadi kesukaan para turis domestik dan international yaitu Klapertart.

Tetapi melihat sebegitu banyaknya manfaat yang bisa di dapat dari tanaman kelapa, belumlah dioptimalkan kekayaannya. Satu bentuk produk yang bisa dikembangkan adalah usaha kerajinan souvenir kayu kelapa.

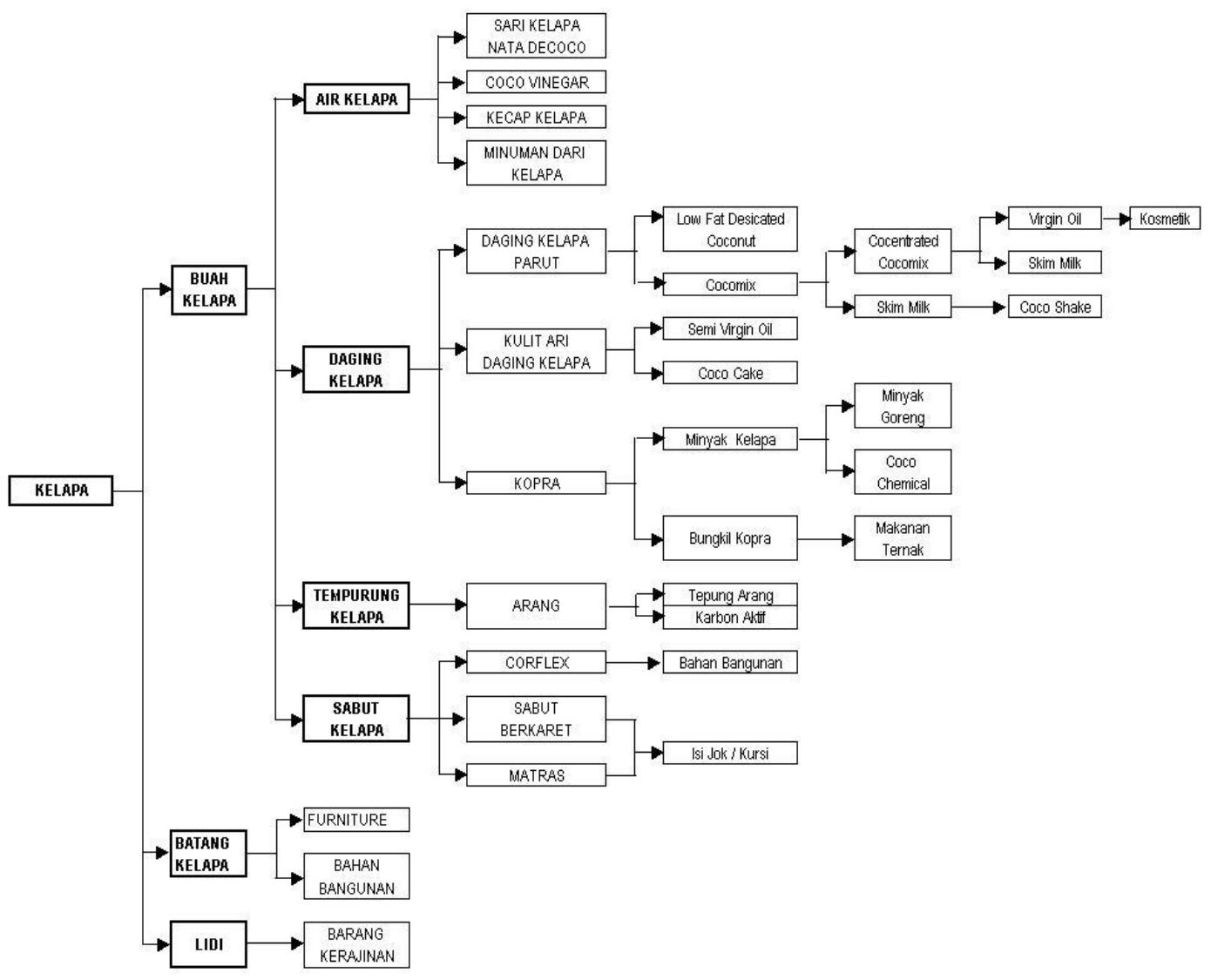

Gambar1. Produk Turunan Kelapa 


\section{Definisi Produk Pariwisata.}

Ada beberapa cara untuk mendefinisikan produk pariwisata. Secara umum, sebuah produk adalah setiap yang ditawarkan yang dapat memuaskan kebutuhan atau keinginan konsumen. Produk dapat terdiri dari satu atau suatu kombinasi unsur-unsur, termasuk barang, jasa, pengalaman, pertunjukan, pribadi, tempat, property, organisasi, informasi dan gagasan (Kotler, 2001). Sebuah produk pariwisata termasuk kombinasi komponen-komponen diatas yang menyumbang pada kepuasan wisatawan.

Brass (1997) produk pariwisata dapat diklasifikasi kedalam 2 (dua) unsur utama: attractions and facilities. Attractions adalah daya tarik baik alam, buatan manusia dan kegiatan yang mendorong orang untuk berkunjung kesuatu daerah tujuan wisata. Contoh, burung sanctuary dapat menjadi kunci untuk mendatangkan wisatawan. Facilities, dipihak lain, menyediakan keperluan kepada baik wisatawan juga penduduk lokal, termasuk jalan, jalur kereta api, lapangan udara, tempat parker, rumah sakit, polisi, air minum, listrik dan akomodasi. Bersamaan dengan itu perkawinan antara atraksi dan fasilitas menciptakan serangkaian intangible "subjective experiences" bagi wisatawan yang dikenal dengan produk pariwisata. Bagi wisata binatang langka, produk dapat dibentuk dari kesempatan melihat spesis unik dan pertunjukan yang bersesuaian, sementara fasilitas yang mungkin digunakan seperti jalan, rumah makan, tempat berkemah dan jasa dasar lain.

\section{1). Cendera mata (Souvenir)}

Secara umum kita mengetahui bahwa cendera mata atau souvenir dapat diartikan sebagai tanda mata atau kenang-kenangan. Definisi souvenir yang dikemukakan oleh Collin adalah sebagai berikut: Souvenir is thing bought which reminds you of the place where you bought it sometimes because the name of place is written on it ( 1994). Jadi dapat dikatakan bahwa cendera mata atau souvenir merupakan benda kenangan yang diperoleh atau dibeli di tempat yang dikunjungi dan memiliki kaitan khusus dengan maksud kunjungannya. Hal ini bisa berupa sifat-sifta khas atau unik yang hanya ditemui di tempat itu dan tidak di tempat lain. Benda tersebut bisa berwujud hasil -hasil kesenian, kerajinan, manifestasi unsur-unsur budaya ataupun fenomena alam setempat misalnya: patung atau lukisan Bali, Batik dan kerajinan perak Yogya, kain tenun Silungkang, anggrek hitam kalimantan, kain krawang Gorontalo dan lain-lain.

\section{2). Industri Pariwisata (Tourism Industri)}

Industri pariwisata atau tourism industry di definisikan oleh Stear sebagai berikut : Tourism industry is a TDR- originating network of strategic collaborative, cooperative, cinfictual and competitive relationships that exist among firms and organisations which direct all or part of their activities at identifying and satisfying specifically touristic and tourismic needs (1998). Dalam operasional kepariwisataaan, suatu industri tidak dapat berdiri sendiri karena diantara industri-industri pariwisata ini ada keterkaitan yang sangat erat dan saling mempengaruhi. Misalnya toko cendera mata atau souvenir shop atau shop which sells souvenirs (Collin, 1994) tidak dapat beroperasi sendiri tetapi 
harus meningkatkan hubungan dengan industri lain misalnya dengan hotel dan transportasi. Hal ini menjadi sangat penting karena kegagalan salah satu indurtri pariwisata akan mempengaruhi citra seluruh daerah sekitar lokasi industri pariwisata terdekat.

\section{3). Pariwisata dan Wisatawan}

Pariwisata biasanya diartikan dengan semua kegiatan yang menyangkut perjalanan. Pariwisata merupakan suatu perjalanan yang bertujuan untuk rekreasi yang dilakukan tidak jauh dari tempat kediaman yang sebelumnya telah direncanakan. Orang yang melakukan perjalanan wisata disebut wisatawan atau turis. Spilanne mendefinisikan wisatawan sebagai pengunjung sementara yang tinggal sekurang-kurangnya 24 jam di negara yang dikunjungi dan tujuan perjalannya untuk keperluan rekreasi, liburan, kesehatan, studi, keagamaan, olahraga, hubungan dagang, sanak keluarga, handai taulan, konferensi dan misi (1987). Wisatawan memiliki profil tersendiri dan merupakan karakteristik spesifik dari jenis-jenis wisatawan yang berbeda dan berhubungan erat dengan kebiasaan, permintaan dan kebutuhan mereka dalam melakukan perjalanan. Dengan demikian penting untuk mengerti profil wisatawan dengan tujuan untuk menyediakan kebutuhan perjalanan wisatawan dan untuk menyusun program promosi dan efektif. Marpaung mengemukakan bahwa berdasarkan karakteristiknya profil wisatawan di kategorikan sebagai berikut: kebangsaan, umur, jenis kelamin, status, latar belakang sosial ekonomi dan budaya (Marpaung: 2000).

\section{METODE PENELITIAN}

Penelitian ini direncanakan pada lokasi usaha yaitu di Wenang Asri Pineleng untuk melihat dari dekat proses pembuatan souvenir serta tempat pemasaran souvenir yaitu di Manado dan sekitarnya. Data Primer diperoleh dari lokasi tempat usaha serta beberapa tempat pemasaran souvenir yang berada di sekitar wilayah Manado dan sekitarnya. Untuk Data sekunder diperoleh dari buku-buku teks pariwisata dan ekoturisme. Untuk keperluan penelitian ini, data dikumpulkan dari lokasi usaha pembuatan souvenir, serta tempat penjualan souvenir. Pengumpulan Data dilakukan dengan cara Observasi dengan melakukan pengamatan dari dekat proses pembuatan souvenir serta pengambilan gambar serta pencatatan data yang relevan dengan judul yang diangkat, selanjutnya dengan wawancara yakni mengajukan beberapa pertanyaan kepada responden dengan instrumen yang digunakan adalah interview guide, kemudian diambil juga dokumentasi yakni pengumpulan data-data yang relevan baik dari objek penelitian maupun dari literatur yang mendukung penelitian. Untuk menjawab permasalahan dalam penelitian ini maka analisis yang digunakan adalah analisis deskriptif kualitatif. Analisis kualitatif adalah suatu analisis yang bersifat memberikan keterangan dan penjelasan tentang objek yang diteliti. 


\section{Sejarah Usaha Kerajinan Tradisonal Wenang Asri Pineleng}

Bermula dari rasa hobi serta karakter jiwa seni yang ada dalam jiwa sosok pribadi yang berprofesi sebagai dokter gigi serta dosen di fakultas kedokteran Universitas Sam Ratulangi Manado, Drg. Yongky Tirtamulia mengoleksi bendabenda kecil hasil kerajinan rakyat dari berbagai daerah yang dikunjungi beliau, serta dari Sulwesi Utara sendiri. Bersama dengan isteri tercinta yang berprofesi yang sama juga Drg. Yoenda Suwantoro mereka bersepakat mendirikan Wenang Asri

Wenang ASRI itulah nama usaha rumah produksi dan penjualan souvenir yang berada di Sulawesi Utara, lebih khusus berada di Pineleng yang masuk Kabupaten Minahasa Induk yang kalau dilihat secara geografi lebih berdekatan dengan Manado. Dinamai "Wenang" karena diambil dari nama lain Manado serta ASRI atau Seni.

Sekitar 12 tahun yang lalu bermula dari sewa counter kecil yang berada di salah satu space di Bilangan Matahari Departement Store Jl. Sam Ratulangi. Usaha penjualan barang tradisional dari Bpk Yongky ini dimulai dengan menjual koleksi barang-barang seni dari berbagai daerah.

Tertantang oleh rasa ini membangun daerahnya melalui berbagai pertemuan yang dilakukan dengan pemerintah Sulut, khususnya bagian pariwisata, maka tercetuslah 2 tahun kemudian Usaha Kerajinan kecil yang diberi Nama Wenang Asri yaitu di medio tahun 2000. Dengan bekal peralatan yang sederhana serta dikumpullah para tukang kecil yang berlokasi diseputar kediaman beliau di daerah Pineleng, dengan satu tekad demi membangun propinsi Sulawesi utara serta kota manado khususnya, menghasilkan plaket-plaket untuk kegiatan event daerah serta pernik-pernik kecil berupa gantungan kunci dengan bahan baku dasar dari kelapa serta kayu dan bambu yang telah diukir sedemikian rupa.

Tahun 2005 pendiri Wenang Asri Bpk Drg. Yongky Tirtamulia meninggal. Namun usahanya masih tetap berjalan. Sekarang ini usaha tersebut dijalankan oleh isterinya Drg. Yoenda Suwantoro. Rasa ingin menutup usaha ada dalam hati ibu melihat kesibukan sebagai dokter dan dosen serta tanpa subsidi atau bantuan modal atau peralatan dari pihak lain atau pemerintah. Namun usaha ini tetap jalan mungkin karena keterikatan emosi dengan almarhum bapak serta rasa ingin membantu para pekerja seputar tempat tinggal, tapi buktinya usaha masih tetap berjalan dan telah menajadi tempat praktek bagi siswa sekolah jurusan tehnik kerajinan.

\section{Struktur Organisasi Kerajinan Tradisional Wenang Asri}

Untuk struktur organisasi di Wenang Asri Pineleng sederhana berbentuk garis/line. Manager adalah Drg. Yoenda Suwantoro, bagian Purchase tugasnya melakukan pembelian dan menerima order pemesanan, bagian Produksi tugasnya melakukan pembuatan / pengerjaan terhadap barang-barang seni, dan bagian Penjualan tugasnya untuk penjulan terdapat di 2 (dua) tempat lokasi untuk bisa mendapatkan yaitu di Wenang Asri Art Shop berlokasi di samping kir i jalan arah Desa Pineleng serta di Jalan Sam Ratulangi samping Kantor Metrologi Manado 


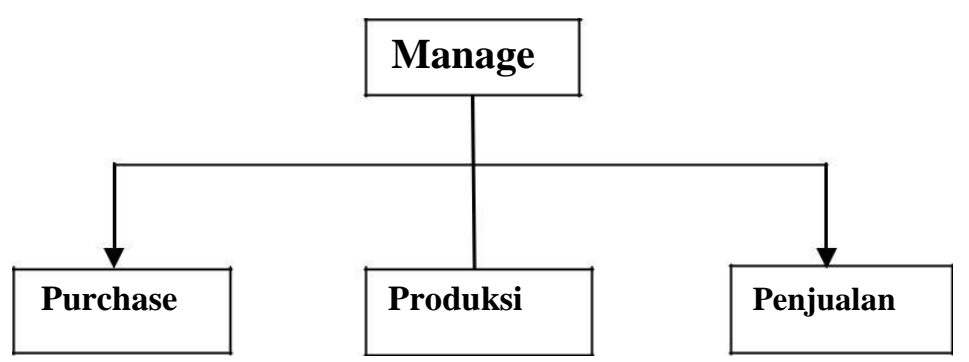

Gambar2. Struktur organisasi Wenang Asri

\section{Tenaga Kerja}

Adapun Wenang ASRI memperkerjakan 5 (lima) tenaga kerja dengan latar belakang pendidikan serta pengalaman kerja masing-masing.

Tabel 1. Tanaga Kerja dan Pendidikan

\begin{tabular}{|c|c|c|c|c|}
\hline No. & Nama & Asal & Pendidikan & Lama Kerja \\
\hline 1. & Joko Sutikno & Jepara (Jawa) & SMA & 5 tahun \\
\hline 2. & Alex W & Manado & SMA & 4 tahun \\
\hline 3. & Will & Minahasa & SMK & 4 tahun \\
\hline 4. & Nita & Manado & SMA & 4 tahun \\
\hline 5 & Nani & Manado & SMA & 4 tahun \\
\hline
\end{tabular}

Sumber: Wenang Asri

\section{Bahan Baku Produksi dan Peralatan}

Adapun bahan baku utama yang dipakai untuk usaha kerajinan produksi souvenir adalah kayu kelapa, batok kelapa / tempurung, kayu cempaka, kayu merah, trileks, sedangkan bahan baku tambahan meliputi paku, kertas pasir, lem kayu, vernis cat. Untuk peralatan yang dipakai dalam mengerjakannya souvenir tersebut yaitu gergaji kecil / besar, gergaji tripleks, skap, bor, alat ukur; meter dan kuas cat.

Berikut contoh gambar bahan baku, proses pengelolahan sampai menjadi souvenir

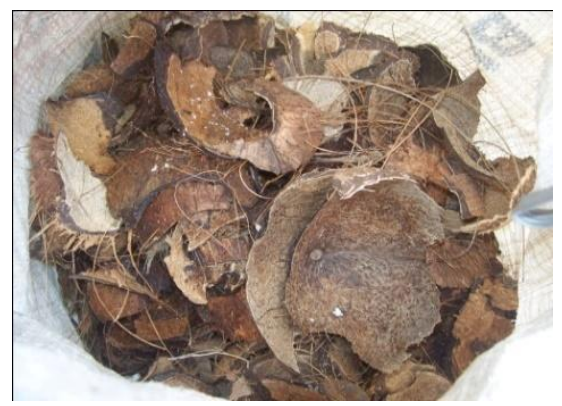

Gambar3. Bahan baku batok kelapa/tempurun 

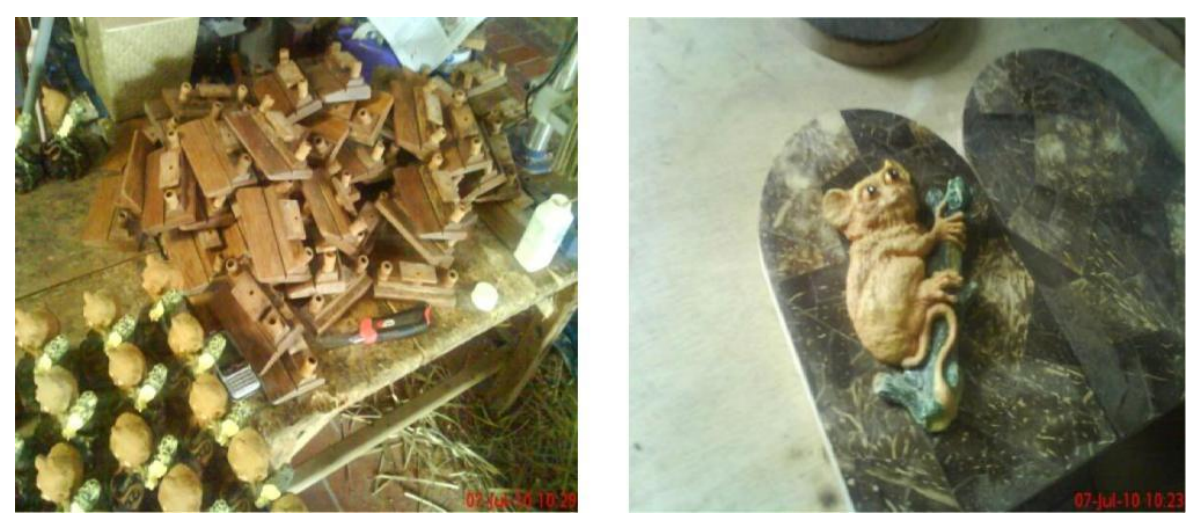

Gambar 4. Menjadi barang $1 / 2$ jadi
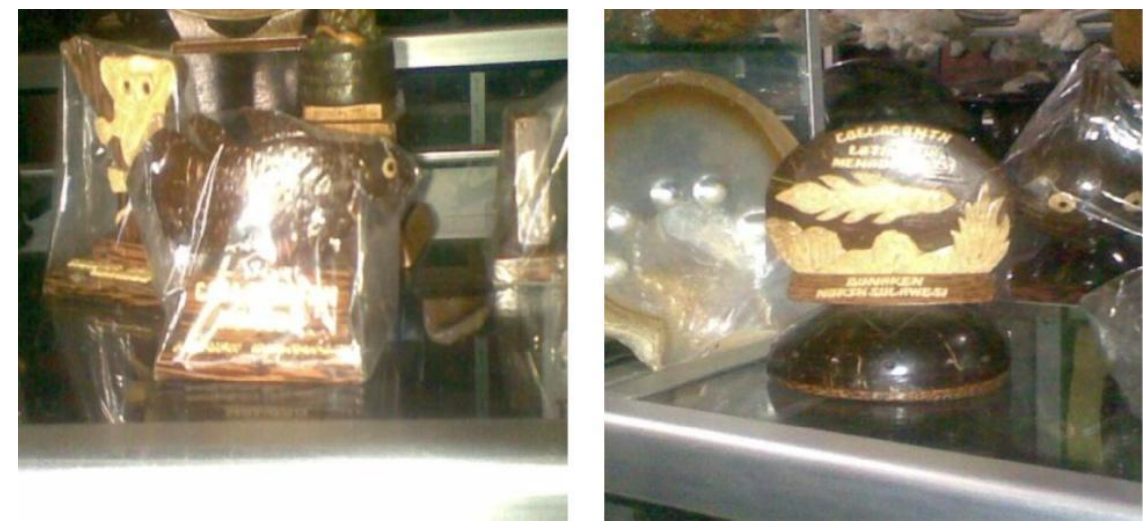

Gamabar5. Contoh souvenir yg sudah jadi /siap dijual

\section{Chanel Penjualan}

Untuk memperoleh produk kerajinan Wenang ASRI dapat di peroleh di dua toko (artshop): Wenang ASRI Art Shop yang berlokasi di samping jalan arah jalan ke Pineleng (Minahasa dan Art Indic yang berlokasi di jalan Sam Ratulangi samping Kantor Metrologi Manado.
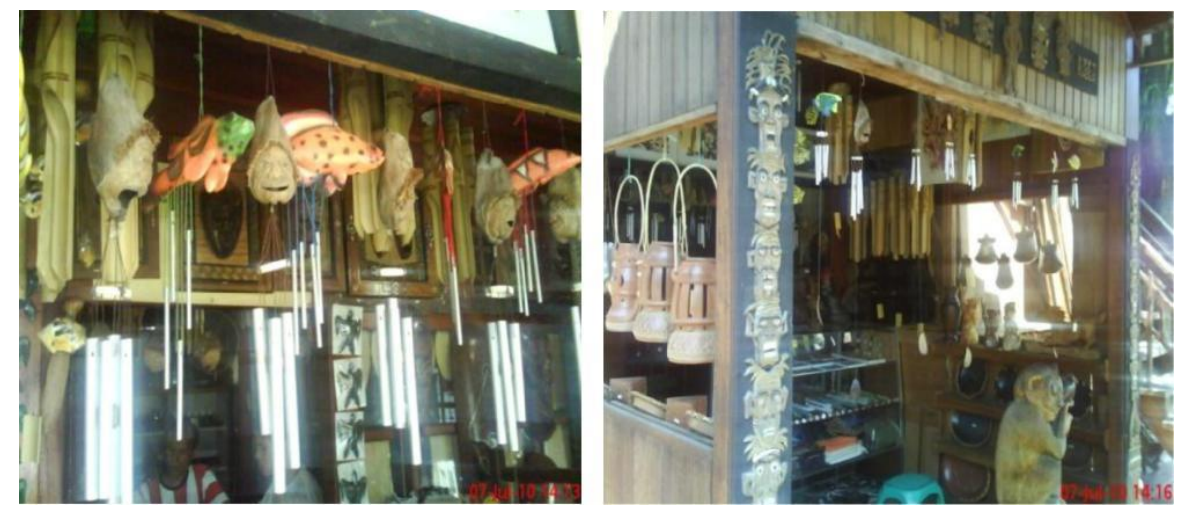

Gambar 6. Lokasi penjualan souvenir terlihat pada salah satu depan Art sIndic shop berlokasi di Jl. Sam Ratulangi, terpasang berbagai produk souvenir yang bahan dasarnya terbuat dari kelapa. 


\section{HASIL DAN PEMBAHASAN}

Untuk mengetahui mengetahui sejauh mana prospek souvenir kelapa tentunya kita melihat bagaimana tingkat peminat produk, keunikan serta volume produk yang dihasilkan dalam beberapa bulan, seperti terlihat pada tabel berikut ini

Tabel 2. Peminat produk kerajinan

\begin{tabular}{|c|c|c|c|c|}
\hline No & Peminat & Asal & Kegiatan & Prosentase Pasar \\
\hline 1 & Domestik & Lokal \& Nasional & Event /Daerah & $80 \%$ \\
\hline 2 & International & Belanda, Itali, Prancis, Asia & Souvenir & $10 \%$ \\
\hline
\end{tabular}

Sumber: Art Shop Indic

Pada table 2 terlihat jelas bahwa rata-rata peminat produk souvenir $80 \%$ adalah local dan nasional ini menujukkan daya serap produk ini hanya diminati oleh orang lokal dan nasional. Inipun dibeli untuk dipakai pada acara event-event daerah yaitu pada seminar dan juga wisudawan, sedangkan 10\% lainnya diserap oleh pasar international sebagai ole-ole (gift) dibawa ke luar.

Berikut ini ditampilkan jenis produk kerajinan yang dihasilkan oleh Wenang Asri, terlihat jelas pada tabel dibawah ini.

\section{Tabel 3. Jenis produk kerajinan dan bahan baku}

\begin{tabular}{|c|l|l|}
\hline No & \multicolumn{1}{|c|}{ Jenis Produk } & \multicolumn{1}{c|}{ Bahan Baku Dasar } \\
\hline 1. & Patung & Kayu Cempaka / Gopasa \\
\hline 2. & Plaket ukir & Kayu kelapa/tempurung/kayu \& fiber \\
\hline 3. & Ukiran hiasan meriam & Kayu Kelapa \\
\hline 4. & Gayung & Tempurung \& kayu \\
\hline 5. & Sendok Kelapa & Tempurung \& kayu \\
\hline 6. & Topeng & Buah kelapa \\
\hline 7. & Ukiran hiasan kapal & Kayu cempaka \& kelapa \\
\hline 8. & Ukiran hiasan topeng dinding & Buah kelapa \& kayu (papan) \\
\hline 9. & Vas bunga & Batok /tempurung kelapa \\
\hline 10. & Piring & Batok kelapa \& kayu \\
\hline 11. & Patung Coelacanth & Kayu kelapa \& batok kelapa \\
\hline 12. & Patung tarsius & Kayu kelapa \& fiber \\
\hline 13. & Asbak & Batok kelapa \\
\hline 14. & Hiasan gantungan & Buah kelapa \& pipa besi \\
\hline 15. & Gantungan kunci & Batok kelapa \\
\hline 16. & Mangkuk & Batok kelapa \\
\hline 17. & Lain-lain & Kayu, kerang, fiber, kayu kelapa \\
\hline Sin & Weang ASR & \\
\hline
\end{tabular}

Sumber: Wenang ASRI

Dengan melihat tabel 3 menunjukkan begitu kompleksnya usaha ini walaupun tidak didukung peralatan banyak, tapi menujukkan konsistensi usaha walaupun daya serap pasar masih didominasi oleh lokal dan nasional. 
Berikut ini ditampilkan volume produksi per bulan untuk produk berbahan baku kelapa dalam lima bulan terakhir dibawah ini.

Table 4. Tabel Volume produksi per bulan untuk produk berbahan baku kelapa bulan maret s/d juni 2010

\begin{tabular}{|c|c|c|c|c|c|c|c|c|}
\hline & & \multicolumn{5}{|c|}{ Per Bulan / buah } & & $\begin{array}{c}\text { Prod } \\
\text { rata- } \\
\text { No }\end{array}$ \\
\cline { 3 - 8 } & $\begin{array}{c}\text { Jenis } \\
\text { Produk } \\
\text { rata } \\
5 \text { bln }\end{array}$ & $\begin{array}{c}\text { Prosentasi } \\
\text { Rata2knaikan } \\
\text { Prod Per Bln }\end{array}$ \\
\hline 1. & Plaket ukir & 220 & 220 & 350 & $\underline{300}$ & 420 & 302 & $21.2 \%$ \\
\hline 2. & $\begin{array}{c}\text { Ukiran } \\
\text { hiasan } \\
\text { meriam }\end{array}$ & 120 & 120 & $\underline{150}$ & $\underline{200}$ & $\underline{150}$ & 148 & $6.7 \%$ \\
\hline 3. & $\begin{array}{c}\text { Gayung } \\
\text { Kelapa }\end{array}$ & 230 & $\underline{240}$ & 260 & $\underline{280}$ & $\underline{260}$ & 254 & $13.2 \%$ \\
\hline 4. & $\begin{array}{c}\text { Sendok } \\
\text { Kelapa }\end{array}$ & 80 & 80 & 80 & 80 & 80 & 80 & $0 \%$ \\
\hline 5. & $\begin{array}{c}\text { Topeng } \\
\text { Kelapa }\end{array}$ & 60 & 60 & 60 & 60 & 60 & 60 & $0 \%$ \\
\hline 7. & $\begin{array}{c}\text { Hiasan } \\
\text { gantungan }\end{array}$ & 60 & 60 & 60 & 60 & 60 & 60 & $0 \%$ \\
\hline 8. & $\begin{array}{c}\text { Gantungan } \\
\text { kunci }\end{array}$ & 60 & 60 & 60 & 60 & 60 & 60 & $0 \%$ \\
\hline
\end{tabular}

Sumber: Data olahan peneliti

Keterangan : pada angka yang di-underline menujukkan produksi per unit naik-turun

Pada tabel 4. menujukkan prosentasi rata-rata produksi dalam 5 (lima) bulan, untuk plaket ukir 302 unit dengan fluktuasi prosentase kenaikan rata-rata $21.2 \%$, sedangkan untuk ukiran hiasan meriam rata-rata produksi per bulannya 148 unit namun berfluktuasi dengan tingkat prosentasi $6.7 \%$. Pada gayung kelapa juga rata-rata produksi 254 unit per bulan dengan fluktuasi prosentasi kenaikan 13.2\%. Untuk ke-empat produk berbahan dasar sama yaitu kelapa rata-rata produksi bersifat tetap, dengan kenaikan prosentasi per bulan adalah 0\%. Tidak stabilnya prosentasi kenaikan dari produk berbahan dasar kelapa ini disebabkan oleh produksi yang dihasilkan rata-rata hanya bersifat order, karena selera pasar lebih disebabkan oleh event lokal pemerintah. Selaras dengan yang ditampilkan pada tabel 2. tentang peminat produk kelapa didominasi oleh pembeli lokal dan nasional karena hanya dipakai pada acara event-event daerah dan nasional.

Pada tabel berikut ini akan ditampilkan volume penjualan untuk tiga tahun terakhir khususnya produk berbahan baku kelapa. 
Tabel 5. Volume penjualan produk berbahan baku kelapa 2005 s/d 2009

\begin{tabular}{|c|c|c|c|c|c|c|c|c|c|}
\hline & & \multicolumn{6}{|c|}{ Tahun } & \multirow{3}{*}{$\begin{array}{l}\text { Penjuala } \\
\text { n } \\
\text { Rata-rata } \\
\text { /tahun }\end{array}$} & \multirow{3}{*}{$\begin{array}{c}\text { Pros } \\
\text { rata- } \\
\text { kenaika } \\
\text { n per } \\
\text { thn }\end{array}$} \\
\hline $\mathrm{N}$ & Jenis & 200 & 200 & 200 & 200 & 200 & 5 & & \\
\hline o & Produk & 5 & 6 & 7 & 8 & 9 & $\begin{array}{c}\text { tahu } \\
\mathrm{n}\end{array}$ & & \\
\hline 1. & $\begin{array}{c}\text { Plaket } \\
\text { ukir }\end{array}$ & 750 & 768 & 770 & 850 & $\begin{array}{c}115 \\
0\end{array}$ & 4285 & 857 & 12.2 \\
\hline 2. & $\begin{array}{l}\text { Ukiran } \\
\text { hiasan } \\
\text { meriam }\end{array}$ & $\underline{455}$ & $\underline{440}$ & 460 & 470 & 510 & 2335 & 467 & 12.0 \\
\hline 3. & $\begin{array}{c}\text { Gayung } \\
\text { Kelapa }\end{array}$ & 353 & $\underline{365}$ & $\underline{350}$ & 375 & 385 & 1828 & 365 & 9.8 \\
\hline 4. & $\begin{array}{l}\text { Sendok } \\
\text { Kelapa }\end{array}$ & 250 & 275 & 280 & 290 & 310 & 1315 & 263 & 22.2 \\
\hline 5. & $\begin{array}{l}\text { Topeng } \\
\text { Kelapa }\end{array}$ & 150 & $\underline{167}$ & $\underline{145}$ & 167 & 220 & 849 & 169 & 45.0 \\
\hline 7. & $\begin{array}{c}\text { Hiasan } \\
\text { gantungan }\end{array}$ & 125 & 150 & 178 & 190 & 220 & 863 & 172 & 15.3 \\
\hline 8. & $\begin{array}{c}\text { Gantunga } \\
\text { n kunci }\end{array}$ & $\underline{150}$ & $\underline{145}$ & 175 & 257 & 310 & 1037 & 207 & 84.8 \\
\hline
\end{tabular}

Sumber: Data olahan peneliti

Keterangan : pada angka yang di-underline menujukkan penjulan per unit naik-turun

Pada tabel 5. terlihat volume penjualan produk berbahan dasar kelapa selama, 5 (lima) tahun terakhir yaitu dimulai tahun $2005 \mathrm{~s} / \mathrm{d}$ 2009, plaket ukiran penjualannya mengalami kenaikan per unit dengan dengan tingkat terjual per tahun 857 unit serta prosentase kenaiknan per tahun $12.2 \%$. Untuk ukiran hiasan meriam penjualan antara tahun $2005 \mathrm{~s} / \mathrm{d} 2006$ mengalami penurunan sebesar 15 unit, namun tahun 2007 s/d 2009 mengalami kenaikan secara bertahap dengan tingkat rata-rata terjual per tahun 467 unit dengan prosentasi kenaikan sebesar 12.\%. Pada produk gayung kelapa antara tahun 2006 s/d 2007 mengalami penurunan penjualan per unit sebesar 15 unit, namun tahun 2008 dan 2009 mengalami kenaikan unit, sehingga prosentasinya mencapai 9.8\%. Pada sendok kelapa terdapat pengecualian dilihat pada tabel 3. produksi bersifat tetap $0 \%$, pada hal untuk penjualan pada 5 (lima) tahun mengalami kenaikan per unit 263 dengan tingkat prosentasi kenaikan yang cukup signifikan sebesar $22.2 \%$. Untuk topeng kelapa penjualan antara tahun 2006 s/d 2007 mengalami penurunan 22 unit, namun tahun 2008 dan 2009 mengalami kenaikan sebesar 53 unit dengan tingkat rata-rata penjualan per tahun sebesar 169 unit dengan prosentasi kenaikan cukup signifikan $45 \%$. Pada hiasan gantungan produksi bersifat tetap (lihat tabel 5) namun penjulan mengalami kenaikan dengan rata-rata terjual 172 unit per tahun dengan prosentasi kenaikan 15.3\%. Gantungan kunci antara tahun 2005 dan 2006 mengalami penurunan penjulan hanya 5 unit, namun secara bertahap antara 
tahun 2007 s/d 2009 mengalami kenaikan penjulan dengan rata-rata terjual 207 unit, dengan prosentasi kenaikan yang signifikan per tahun mencapai $84.8 \%$.

Jika melihat pada tabel penjualan untuk 3 (tiga) tahun terkahir $2007 \mathrm{~s} / \mathrm{d}$ 2009 mengalami peningkatan penjualan secara bertahap kelihatan begitu baik, apa lagi untuk tahun 2009 terlihat lonjakan penjulan yang signifikan, ini bisa disebabkan oleh adanya 2 (dua) event international yang diselenggarakan di propinsi Sulawesi Utara khususnya di Kota Manado yaitu World Ocean Conference - CTI Summit dan Bunaken Sail. Memang disadari bahwa dua event tersebut telah memperkenalkan Sulawesi Utara di dunia international, dan dampak dari pelaksanaan event tersebut secara langsung terhadap naiknya penjualan dari berbagai produk pariwisata umumnya.

\section{SIMPULAN}

Berdasarkan hasil analisis secara keseluruhan, dapat disimpulkan bahwa rata-rata peminat produk kerajinan rata-rata masih diserap oleh domestik sebesar $80 \%$ yaitu untuk kegiatan event lokal / daerah dan nasional sedangkan internasional hanya $20 \%$.Volume produksi rata-rata souvoner ; plaket ukir kayu kelapa dalam lima bulan berturut mulai dari pebruari, maret, april, mei dan juni 2010 mengalami prosentasi kenaikan $21.2 \%$ diikuti ukiran meriam 67\%, kayu kelapa $13.2 \%$ sedangkan gayung kalapa, sendok, topeng, hiasan gantungan dan gantungan kunci tetap $0 \%$. Untuk volume penjualan lima tahuan terakhir dari tahun 2005 s/d 2009 untuk produk souvener berfluktuasi setiap tahun, hal ini dipengaruhi oleh event yang ada pada tahun tersebut, namun pada dasarnya mengalami rata-rata prosentasi kenaikan yaitu untuk produk plaket ukir $12.2 \%$, ukiran meriam $12 \%$, gayung $9.8 \%, 22,2 \%$, topeng kelapa $45 \%$ dan gantungan kunci $84.8 \%$. Produk usaha dari Wenang Asri memiliki prospek yang baik maka perlu untuk dipertahankan usaha tersebut, hanya perlu manajemen pengelolaan perlu diatur kembali dan tidak berdasarkan manajemen tradisional. Bentuk usaha tetap home industri hanya pengelolaannya harus profesional.

\section{DAFTAR PUSTAKA}

Crompton, John, L. (1979), An Assesment of the image of the Mexico as a vacation Destination and The influence of Geographical Location Upon The Image. Journal of Travel research. 17 (Spring): 18-23

Gartner, W, C. (1986) Temporal Influence on Image Change. Annals of Tourism Research. 13 (4) : $635-44$

Hunt, John, D. (1975), Image as A factor in Tourism Development. Journal of travel research, 13 (winter) : 1-7

Kotler Philip, (1995), Manajemen Pemasaran, Prentice Hall-Salemba Empat, Jakarta 


\section{Tourism Scientific Journal}

Volume 2 Nomor 1 Desember 2016

Kusmayadi dan Endar, S. (2000). Metodologi Penelitian Dalam Bidang Kepariwisataan. Jakarta Gramedia Pustaka.

Maleong, Lexy J. (2004). Metodologi Penelitian Kualitatif. Bandung: Remaja Rosda karya Spillane J. James. (1987). Ekonomi Pariwisata: Sejarah dan Prospeknya.

Kanisius, Yogyakarta. 